OPEN ACCESS

Edited by:

Gary James Harfitt,

The University of Hong Kong,

Hong Kong

Reviewed by:

Paul Betts,

University of Winnipeg, Canada

Vicki Dea Ross,

Northern Arizona University,

United States

*Correspondence:

Sarah Gravett

sgravett@uj.ac.za

Specialty section:

This article was submitted to

Teacher Education,

a section of the journal

Frontiers in Education

Received: 25 September 2018 Accepted: 17 December 2018

Published: 23 January 2019

Citation:

Gravett S, Petersen N and Ramsaroop S (2019) A University and

School Working in Partnership to Develop Professional Practice

Knowledge for Teaching

Front. Educ. 3:118

doi: 10.3389/feduc.2018.00118

\section{A University and School Working in Partnership to Develop Professional Practice Knowledge for Teaching}

\author{
Sarah Gravett ${ }^{1 *}$, Nadine Petersen ${ }^{1}$ and Sarita Ramsaroop ${ }^{2}$ \\ ${ }^{1}$ Faculty of Education, University of Johannesburg, Johannesburg, South Africa, ${ }^{2}$ Childhood Education, Faculty of \\ Education, University of Johannesburg, Johannesburg, South Africa
}

The article reports on the University of Johannesburg's (UJ) efforts at offering a practice-based teacher education program in partnership with a university-affiliated school (a "teaching school") with a view to developing inquiry-oriented novice teachers. The research aimed at exploring what it takes to develop a "learningplace" (Conway et al., 2014) conducive to student teachers' development of professional practice knowledge and the role of mentoring in this regard. A two-phase process of generating data was used. In the first phase, the published research on the university-affiliated school was analyzed, using qualitative content analysis to look for patterns across the historical unfolding of the findings of these papers. In phase two a questionnaire was administered involving final year student teachers in the teacher education program. The research shows that a teaching school, if integrated into the program design and delivery, provides a rich practice learning site for student teachers. In addition, mentoring in cognitive apprenticeship mode could indeed be a powerful contributor to student teachers' professional development. However, the overall programme design is decisive. The preparation of teachers with strong professional practice knowledge requires attention to four interrelated aspects of program design, namely program identity, organizational structures, curriculum, and teacher education pedagogy. Addressing these aspects in an integrated manner would be difficult without working closely with one or more partnership schools.

Keywords: initial teacher education, mentoring, mentor teachers, theory-practice divide, university-school collaboration, school practicum, professional practice knowledge

\section{INTRODUCTION AND CONTEXT}

In many countries the notion that teacher education is too theoretical is widely purported to be the cause of new teachers not coping with the practical aspects of classroom teaching (Darling-Hammond and Baratz-Snowden, 2005; Darling-Hammond et al., 2005; Jones et al., 2016). Smagorinsky et al. $(2003,1400)$ note the perceived disconnect between university-based teacher education and the complex world of classroom teaching as university teacher educators being "aloof within the ivory tower, espousing ideals and the principles that govern them," while teachers engage in practice "in the teeming world of the classroom." Some claim that the coursework in teacher education programs is not relevant to practice, or alternatively, that student teachers do not see the applicability of their coursework (Barrow, 1990; Kosnik and Beck, 2009). 
A similar critique was leveled at South African teacher education. At a Teacher Development Summit in 2009, the prevailing view was that initial teacher education programs foreground theory and neglect the practice demands aligned to the needs of schools (Education Labour Relations Council, 2009). The Summit called for the development of a national plan for teacher development. Subsequently, stakeholders collaborated to develop the Integrated Strategic Planning Framework for Teacher Education and Development in South Africa 20112025 [Department of Basic Education Department of Higher Education Training (DBE DHET), 2011]. The Framework responds to the criticism that teacher education should be more practice-focused and foresees stronger collaboration with schools in teacher education. This policy directive is in line with the practice/practicum turn internationally (Mattsson et al., 2012), which sees schools as sites for workplace learning featuring prominently in teacher education.

In addition, South African teacher education is regulated by the "Policy on the Minimum Requirements for Teacher Education Qualifications" (Department of Higher Education Training., 2015). This policy also highlights the significance of school-based workplace learning for initial teacher education with the assumption that student teachers will be wellsupervised. The work-integrated learning (WIL) ${ }^{1}$ component of initial teacher education qualifications is however riddled with difficulties. These include unfavorable teaching and learning conditions in many school such as overcrowded classrooms, heavy teaching loads of teachers and a lack of time and space to mentor student teachers (Robinson, 2015). Other studies note that teachers are unwilling or reluctant to mentor student teachers (Mutemeri and Chetty, 2011; Odendaal, 2015). In a recent study Gravett and Jiyane (in press) describe how teachers "disappear" from the classroom once student teachers arrive, leaving the student teachers to take charge of the teaching, with little or no mentoring taking place.

It is against this background that we report on the University of Johannesburg's (UJ) efforts at offering teacher education in partnership with a university-affiliated school with the aim of developing inquiry-oriented novice teachers, who have a sound understanding of child development. In this paper, we address the following questions: What have we learned, through an analysis of extant research on the UJ teacher education program, of what it takes to develop a "learningplace" (Conway et al., 2014) conducive to student teachers' development of professional practice knowledge? What role does mentoring play? What are student teachers' views on the role of mentoring and mentor teachers in their learning to become teachers?

We first explain how we designed the program to incorporate a university-affiliated school. Thereafter we explore the literature on the development of teachers' professional practice knowledge, including the role of mentoring. We then move on to the

\footnotetext{
${ }^{1}$ In South Africa the term work-integrated learning (WIL) is used to refer to learning in the workplace - classroom and school settings. The terms school experience and teaching practice are also used. A widely used term in the literature is practicum or school practicum. We use these terms interchangeably in the article.
}

results of a recent investigation into student teachers' views on what and how they learn from mentor teachers ${ }^{2}$-in the university affiliated school and in other schools where they have been placed for WIL. The current research findings are presented against the backdrop of an analysis of research that has been conducted on the program since its inception in 2010 . We use the combined results to argue that despite difficulties encountered, the involvement of the university-affiliated school as "learningplace" for student teachers supports both coursework learning and practice learning. Mentoring undoubtedly plays an important role in this process, but mentoring in, and of itself, is insufficient to bridge the theory-practice divide. In the light of the dire need for well-educated foundation phase teachers ${ }^{3}$ in the country, the question that we have been grappling with is how the work that we have been doing with the school can be replicated. The last part of the article proposes a way forward.

\section{DESIGNING AN INITIAL TEACHER EDUCATION PROGRAM AT THE SOWETO 4 CAMPUS OF THE UNIVERSITY OF JOHANNESBURG TO INCORPORATE A UNIVERSITY-AFFILIATED SCHOOL}

In 2010, on the University of Johannesburg's Soweto campus, the first university-affiliated school to serve as a "teaching school"5 in South Africa, was established. The school's establishment was effected through a partnership with the provincial department of education. Soon thereafter, the Strategic Planning Framework for Teacher Education and Development in South Africa [Department of Basic Education Department of Higher Education Training (DBE DHET), 2011] was developed and published, in which the proposal was made for strengthening the teaching practice/school experience component of teacher education programs through, inter alia, the establishment of teaching schools.

\footnotetext{
${ }^{2}$ Different term are used in the literature to refer to the teachers who are guiding and supporting student teachers in schools, e.g. co-operating teacher, supervising teacher, school-based mentor and mentor teacher. In this paper the latter term is preferred for two reasons - the one is pragmatic - it is the term that is generally used in South Africa. The second reason is because 'mentor teacher' best captures the role that we think the teachers who are involved in the school practicum (should) play.

${ }^{3}$ The University of Johannesburg offers two four year Bachelor of Education degrees for the primary school namely a BEd in Foundation Phase Teaching and a BEd in Intermediate Phase Teaching. The foundation phase is the first four years of schooling - grades R (reception year - first year of formal schooling) to grade three and the intermediate phase involves grades four to six. Though the article refers to both programs, the foundation phase program preceded the intermediate phase program. The intermediate phase program started four years later.

${ }^{4}$ Soweto is an urban township situated to the southwest of Johannesburg.

${ }^{5}$ When this school was established, we used the terms experimental school or university school or research school interchangeably to refer to the school. We adopted the term "teaching school" after the promulgation of the Integrated Strategic Planning Framework for Teacher Education and Development in South Africa, which refers to schools in the system dedicated to serve as "teaching laboratories where student teachers can engage in learning-from-practice" as "teaching schools".
} 
We designed the BEd in Foundation Phase Teaching with a view of offering a program in which student teachers would experience congruence between coursework learning and practice learning in the school. We envisaged concrete experience in the school providing student teachers with opportunities to systematically study, analyze and theorize practice (Gravett, 2012) during coursework and vice versa. The program design was also informed by the view that prospective foundation phase teachers need to study the development of young children closely in order to develop a solid understanding of how children learn, change and develop over time. Our aim was for student teachers to develop "a pedagogical stance rooted in knowledge of child development” (Feiman-Nemser, 2001, 1018).

Consequently, the curriculum construction and the student teachers' involvement in the teaching school reflect the centrality of child study, which is a chief focus of one of the academic majors, with incorporation into other courses as well. The coursework directs student teachers' observations in the school via observation tasks. First year student teachers observe Grade $\mathrm{R}$ children, student teachers in the second year of study observe Grade 1 children, and in the third year, student teachers study the learning and the development of Grade 2 and 3 children. Lastly, in their fourth year they integrate all the dimensions of their studies. In addition, each student teacher is assigned one child for in-depth study over a period of four years. The teaching school also serves other purposes. Student teachers provide classroom assistance to the teachers. They also undertake limited teaching at the school under the guidance of the universitybased teacher educators and mentor teachers. In addition, they participate in service learning projects involving the school learners. To broaden student teachers' experiences of the wider schooling context, they are also placed at other schools for WIL.

\section{DEVELOPING STUDENT TEACHERS' PROFESSIONAL PRACTICE KNOWLEDGE}

\section{Professional Practice Knowledge}

It is widely acknowledged that student teachers need to learn knowledge of teaching and knowledge from teaching in tandem during their teacher education years. However, how to execute this is an enduring conundrum. Part of the problem is what Horn and Campbell $(2015,151)$ refer to as "The Learning Outcome Dilemma" - should teacher education programs prepare teachers "for the schools that are or the schools that should be"? We maintain that teachers must be equipped for both. Teachers must first be able to function in the schools that are. However, we also need to prepare "transformative agentic teachers" (Orland-Barak, 2017, 250) who would be able to work in diverse environments, pursue social justice in education and negotiate the increasing complexity of a fast changing world. Teachers' work is not static-it is changeable and complex, which requires adaptive expertise (Feiman-Nemser, 2008, 700). This implies that teachers need to develop a "multi-faceted knowledge base" (McNamara et al., 2014, 12) as well as a "repertoire of skills, strategies and routines, and the judgement to figure out what to do when" (Feiman-Nemser, 2008, 700).

We argue that the best way to prepare student teachers for these imperatives is to offer inquiry-oriented, practice-based teacher education. To us this means that productive learning experiences in schools-teachers' practice sites-are essential, coupled with giving "sustained attention to the 'why' of teaching and therefore teacher education" (Childs et al., 2014, 37). These authors see an emphasis on the "why" as central to recognizing teaching as a profession. We view this as central to the development of an inquiry-orientation.

Here we find the different knowledges needed for developing the professional knowledge base of teachers instructive. Referring to Aristotle, Ulvik and Smith (2011) discuss knowledge in terms of episteme, techné and phronesis. Episteme (knowing that) refers to scientific understanding (Kessels and Korthagen, 2001, 24) or propositional knowledge (Kessels and Korthagen, 2001, 23) and is often used synonymously with theoretical knowledge. Techné is about knowing how to act (practical skills) while phronesis, or practical wisdom, is about "wise practical reasoning" (Eisner, 2002, 375). Eisner's description of what practical reasoning involves, makes its relevance for teachers and teaching obvious. Practical wisdom is, inter alia, deliberative, it takes account of context and addresses particulars, it considers trade-offs, it deals with contingencies and it shifts aims in process when necessary. Wise practical reasoning is essential for teachers because of the complexity of teaching and classrooms. Teachers must be able to make appropriate, contextually relevant teaching decisions in the moment.

We agree with Ulvik and Smith (2011) that teacher education needs to include all these knowledges. However, we are convinced that pursuing theoretical knowledge in teacher education programs as an end in itself perpetuates the theory-practice disjuncture (Kessels and Korthagen, 2001). McIntyre (1995, 377378) says that,

"Theorizing should indeed be practical. The focus must be on what will help student teachers themselves to think critically and productively about how to teach and, more generally, about how to engage in the practice of schooling. ... 'Theory' which is not clearly directed to such practical ends is indeed a burden for student teachers, a burden which most of them cast aside as soon as possible. But theory-based ideas used to guide practice and to theorize about good practice, justify themselves through the benefits which they bring".

Ideas from theory become generative and valuable to student teachers when used as lenses to generate questions, explore educational dilemmas and student teachers' views, and to juxtapose different perspectives.

Practical wisdom is developed through experience. Consequently, the development of wise professional practice should be in focus during student teachers' practicum (Mattsson et al., 2012). But merely observing and experiencing teaching does not necessarily result in practical wisdom. As Dewey (1933, 25) pointed out: "the belief that all genuine education comes about through experience does not mean that all experiences are genuinely or equally educative." The type of experience that is required for developing of practical wisdom includes "assessing 
situations, judging, choosing courses of action, and being confronted with their consequences" (Kessels and Korthagen, 2001, 27).

\section{Schools as "Learningplaces" for the Development of Professional Practice Knowledge}

Graduates from teacher education programs often refer to the practicum as the most valuable part of teacher education (Mattsson et al., 2012; Loughran and Hamilton, 2016). However, learning in the practicum can be rather superficial-not moving beyond teaching activities and classroom routines (the how of teaching) and serving merely to socialize student teachers into the status quo which may "lead to a reproduction of traditional habits and norms" (Korthagen, 2016) of which some may be undesirable. We concur with Conway et al. (2014) that while schools are envisioned as sites for learning in initial teacher education, in general, schools do not foreground the learning of student teachers intentionally. For a school to serve as a site for meaningful workplace learning it needs to be reframed as a "learningplace" for the development of professional practice knowledge of student teachers.

Therefore, attention should be paid to the design features that make school-based experiences educative (Zeichner and Bier, 2015).

So what are these features? We briefly explore three.

A core issue is how the practicum's purpose is conceptualized. Generally, the practicum is broadly conceived as apprenticeship-student teachers are supervised by an experienced teacher who models classroom practices and who guides and supports them to learn these practices. We argue that an apprenticeship approach is not adequate for ensuring a truly "educative experience" and supporting the acquisition of practical wisdom and judgement. We draw here on Dewey (1904) who distinguishes between practice work as apprenticeship and practice work of the laboratory kind. The apprenticeship and laboratory perspectives on practice work are not mutually exclusive, but the point of departure of the two perspectives differs fundamentally. Practice work with an apprenticeship focus aims at equipping student teachers with the necessary tools for teaching, including teaching and classroom management strategies and skills - the aim is thus practical. The main intent of practice work with a laboratory focus is to develop a thoughtful teacher through supplying of "intellectual method," with the aim of provoking "intellectual reactions" (Dewey, 1904, 34), as well as to support experimentation. On the other hand, laboratory practice work does not exclude apprenticeship practice work. However, in laboratory practice work, the analysis of the student teachers' observations and inquiry into classroom events is prominent, together with invoking theoretical lenses to explore observations and events experienced, with a view to arriving at "informed practice" (White and Forgasz, 2016, 233). To us this is commensurate with the notion of developing expertise through cognitive apprenticeship (Collins et al., 1991).

Cognitive apprenticeship is a model of instruction that works to make thinking visible (Collins et al., 1991). During the practicum it would involve both the thinking of the mentor teacher and the student teacher. Ways to promote expertise, as put forward by these authors include the four aspects of traditional apprenticeship which are often used by mentor teachers namely, modeling, coaching, fading, and providing support through scaffolding. The authors add three other aspects for promotion of expertise, of which two are pertinent for developing practical wisdom and judgement, namely articulation and reflection. Combined it means getting student teachers to articulate their thinking, reasoning, or problem-solving processes underlying an executed task (the why), compare their performance to the features of expert performance and relate their performance to coursework learning (theory).

A second design feature that makes school-based experiences educative is purposive mentoring. Clarke et al. (2014) did an extensive review on the literature of cooperating teacher participation in teacher education. They identified 11 ways in which these teachers' work is conceived and enacted: providers of feedback, gatekeepers of the profession, modelers of practice, supporters of reflection, gleaners of knowledge, purveyors of context, conveners of relation, agents of socialization, advocates of the practical, abiders of change, and teachers of children. They make the case that an understanding of these can aid teacher educators to provide support to mentor teachers.

It is widely claimed that mentor teachers are the most powerful influence on the quality of the practicum experience and often shape what student teachers learn (Clarke et al., 2014, 66). This underscores the need to articulate a clear conception of the mentor teacher's role (Stanulis and Russell, 2000). Clarke et al. (2014, 188), drawing on Gaventa's (2007) typology of participation makes the case for this role clarification to be addressed within an "invited space." This implies that there is some negotiation between the authority or more powerful partner (generally the teacher education institution) and the others (the mentor teachers) about the ways in which they will participate in order to arrive at a shared understanding of the purpose of the practicum and the roles and responsibilities of the different roleplayers. Working with similar "whys" enables discursive alignment of purpose.

Being a good teacher, or even an expert teacher (Hattie, 2003) does not necessarily mean that one becomes a good mentor (Ganser in Krull, 2005; Smith and Ulvik, 2014). Mentoring consists of complex social interactions that both mentor teachers and student teachers need to negotiate for student teachers to achieve professional growth and development (Fairbanks et al., 2000). Smith and Ulvik (2014) argue that mentoring competence demands professional knowledge and skills acquired through mentor education. Thus, development of teachers to fulfill adequately the role of mentor teacher is crucial. Development efforts need to put considerable emphasis on distinguishing between the "passage from being a classroom teacher to functioning as a mentor of teachers" (Orland-Barak, 2017, 113).

Mentor teachers also need to acquire competence in directing mentoring dialogues that are supportive, yet challenging. They need to learn how to provide productive feedback and feedforward (Smith and Ulvik, 2014). The type of feedback that mentor teachers generally give tend to be "narrow, particularistic, 
and technical" (Clarke et al., 2014, 175) when they actually need to provide feedback that promotes "deep and substantive reflection on practice" (Clarke et al., 2014, 175). They must also be guided how to analyze their own work, question their own practices and develop their own teaching (Smith and Ulvik, 2014). This will enable them to more readily share their thinking processes and "adaptive decision-making processes" (Zeichner and Bier, 2015,23) with student teachers.

Another design feature that makes school-based experiences educative is congruence between coursework learning and student teachers' experiences during practicum. One of the reasons for the theory-practice dilemma in teacher education, and why learning in the practicum is often superficial, is the gap between what student teachers learn in coursework and what they experience in schools (Darling-Hammond and BaratzSnowden, 2005; Darling-Hammond et al., 2005; Intrator and Kunzman, 2009; Korthagen, 2010; Zeichner, 2010; Cheng et al., 2012). Darling-Hammond $(2000,8)$ refers to this disconnect as the "Achilles heel of teacher education."

The gap between coursework and practicum experiences has several possible ramifications for student teachers. They may start to question the value of the practicum (Jones et al., 2016) or the value of coursework (theory) for teaching in "the real world." They may also find themselves caught between the views and expectations of the university teacher educators and those of mentor teachers. Day $(1998,808)$ in White and Forgasz $(2016$, 238) summarizes this tension as follows: student teachers have to "learn to cope with different imperatives alongside continuing skepticism by school-teachers of the theory-bound esoteric world of the academic which contrasts with the perceived practicebound action worlds in which they work."

Congruency between coursework learning and school experience learning is the ideal, but achieving such congruence is challenging, particularly if student teachers are placed in a variety of schools. This is one of the reasons why universities opt to establish partnerships with specific schools. We agree with Flores $(2016,218)$ that enduring, coherent and supportive partnerships between teacher education institutions and schools is "at the heart of challenging the binary of theory and practice."

\section{METHODS}

We used a two-phase process of generating data. In phase one we reviewed the published research on the teaching school during the period 2010-2017-these comprised five journal articles (Gravett, 2012; Gravett et al., 2014; Gravett and Ramsaroop, 2017; Ramsaroop and Gravett, 2017; Loukomies et al., 2018). Using qualitative content analysis (Merriam, 1998) we looked for patterns across the historical unfolding of the findings of these papers, reflecting the views of multiple role players; focusing specifically on how the teaching school operates as a space for student teachers to learn in and from practice, and what their mentoring in this learning comprises. From this chronological process of content analysis, we distilled three main themes.

In phase two, we administered a questionnaire to the 2018 cohort of final year students in the primary school teacher education program $(n=143)$ comprising some questions with a Likert-scale type response as well as a set of open-ended questions. In the first part of the questionnaire students were asked to respond on a five-point scale with $1=$ not at all and $5=$ very much, to questions about their learning from mentors during practice teaching and the quality and extent of the mentoring they received. In the open-ended questions, we asked them to identify characteristics of an excellent mentor with an explanation of why they had chosen specific traits. The combination of question types allowed us to elicit responses to key aspects of mentoring that we identified, while still allowing sufficient flexibility for student teachers to express what they considered important and how their personal experiences (Merriam, 1998; Henning et al., 2004) of mentoring in schools was influenced.

When the teaching school was established a rigorous process was put in place for research in and related to the school, captured in an overarching ethics clearance document, which was approved by the UJ Faculty of Education Ethics Committee. The UJ Faculty of Education Ethics Committee provided overarching ethics clearance for teaching school related projects with the rider that the governance structure /committee that oversees the teaching school related research must ensure that the guidelines approved by the Faculty of Education Ethics Committee are implemented. Therefore, there was no requirement to submit this project for individual ethics clearance. All participants gave written informed consent in accordance with the Declaration of Helsinki.

The responses to the questionnaire were analyzed descriptively and detailed in terms of position (percentage in the data) and dispersion (range of responses) and captured in a table and a graph. Here our aim was to describe the basic features of the data. For the open-ended responses, we used a process of inductive thematic analysis (Henning et al., 2004), moving from individual codes to categories and then looking for patterns across the categories. For instance, student teacher utterances such as "my mentor was welcoming" or "she showed me kindness" were grouped under the umbrella category of "mentoring as care/caring." Once we had a number of such categories described, we could refine these and identify emerging patterns across the various categories. This process resulted in a number of themes in the next section.

We then compared these findings with the three themes that had been distilled from the published research to identify common patterns across the two sets of data with a view of responding to the research questions-this forms the basis of the discussion section.

\section{QUESTIONNAIRE RESULTS}

\section{Mentoring Through Observation}

Student teachers described learning through observation of their mentor teachers and indicated that mentors "lead by example." Most student teachers allude to learning about the basic operational functionality of the school and classroom, i.e., "being punctual," adhering to school rules, ensuring that "teaching and learning takes place each day" and being "prepared for lessons."

Secondly, student teachers described how mentors promoted engaging practice and created disciplined and orderly learning 
TABLE 1 | Frequency of responses: how much student teachers $(n=143)$ learned in the teaching school (TS) and WIL schools, respectively.

\begin{tabular}{|c|c|c|c|c|c|c|c|c|c|c|c|c|}
\hline \multirow[t]{2}{*}{ Item in questionnaire } & \multicolumn{2}{|c|}{ Not at all } & \multicolumn{2}{|c|}{ Some } & \multicolumn{2}{|c|}{ Average } & \multicolumn{2}{|c|}{ Quite a lot } & \multicolumn{2}{|c|}{ Very much } & \multicolumn{2}{|c|}{ Not answered } \\
\hline & TS & WIL & TS & WIL & TS & WIL & TS & WIL & TS & WIL & TS & WIL \\
\hline $\begin{array}{l}\text { How to choose teaching strategies to teach } \\
\text { specific content }\end{array}$ & 4 & 27 & 9 & 33 & 47 & 47 & 54 & 20 & 28 & 14 & 1 & 2 \\
\hline How to assess to improve children's learning & 2 & 13 & 6 & 28 & 21 & 46 & 61 & 36 & 52 & 19 & 1 & 1 \\
\hline How teachers should reflect on their lessons & 7 & 29 & 11 & 30 & 23 & 34 & 41 & 34 & 61 & 16 & 0 & 0 \\
\hline How to teach so that learners are engaged & 1 & 4 & 11 & 26 & 31 & 40 & 51 & 42 & 48 & 30 & 1 & 1 \\
\hline $\begin{array}{l}\text { Mentor teachers provide feedback that you can } \\
\text { learn from }\end{array}$ & 3 & 10 & 5 & 14 & 13 & 33 & 50 & 39 & 67 & 42 & 5 & 5 \\
\hline $\begin{array}{l}\text { Mentor teachers provide good reasons for } \\
\text { evaluating in a particular way }\end{array}$ & 4 & 13 & 8 & 23 & 29 & 35 & 55 & 42 & 44 & 27 & 3 & 3 \\
\hline $\begin{array}{l}\text { Mentor teachers help to connect practice to } \\
\text { learning about children's development }\end{array}$ & 5 & 20 & 13 & 17 & 32 & 47 & 47 & 35 & 42 & 19 & 4 & 5 \\
\hline Mentor teachers guide in the delivery of the lesson & 2 & 10 & 17 & 24 & 22 & 41 & 58 & 35 & 41 & 30 & 3 & 3 \\
\hline $\begin{array}{l}\text { Mentor teachers provide positive and constructive } \\
\text { feedback on lesson plans }\end{array}$ & 4 & 5 & 3 & 20 & 13 & 31 & 55 & 45 & 64 & 38 & 4 & 4 \\
\hline $\begin{array}{l}\text { Mentor teachers guide in lesson planning by } \\
\text { making the link to learning in coursework }\end{array}$ & 2 & 19 & 4 & 20 & 21 & 47 & 51 & 31 & 62 & 22 & 3 & 4 \\
\hline
\end{tabular}

environments. There were many such descriptions in the data as evidenced by the following: "she used practical examples in the classroom to make learning easier," "she takes time ... and accommodates all learners," "she knows how to maintain discipline in her class" and "would guide me on how to handle learners behaviors."

\section{Conceptions of Mentors}

Student teachers also described mentoring in terms of the teachers' behavior and characteristics. In terms of the latter the data is replete with descriptions of mentor teachers as "kind," "caring," "understanding," "approachable," and "helpful"-qualities students seem to associate with good mentors.

In terms of the mentors' role in lesson planning and teaching in the classroom, there were some variations in the quality and scope of feedback, but the majority describe being guided in planning lessons and through feedback afterwards. For instance, student teachers detailed how the mentor teacher "goes through the lessons I prepare before I teach, then provides advice" and "compliments me, and tells me where to improve."

\section{Mentoring in the Teaching School}

While there are commonalities in how student teachers describe mentors and mentoring practices in the teaching school and in the WIL schools, the teaching school does provide distinct advantages. The data point to student teachers at the teaching school experiencing mentoring that foregrounds the "why" of classroom practice-in this way mentor teachers' tacit knowledge is more "visible" to students. Some examples from student teachers are evidence hereof: "The mentor teacher helped me understand lesson planning," "my mentor teacher asks critical questions," "the mentor always explains why she taught the lesson in a particular way" and "they (the teachers) connect classroom practice to what we are taught in the lectures."
In particular, student teachers rated their mentoring experiences with regards to lesson observations, lesson planning, delivery, and feedback more positively at the teaching school in comparison with WIL schools (Table 1 and Graph 1). From the student teacher responses, it appears as though their mentoring experiences at the teaching school extend beyond an emphasis on mere procedures. For instance, there are reports of more guidance from mentors at the teaching school $(n=79 \%)$ in terms of student teachers planning lessons and linking their learning with university coursework. At WIL schools, a smaller percentage of student teachers report such experiences $(n=37 \%)$. Student teachers also state that they are learning more about reflection at the teaching school $(n=71 \%)$ in comparison with WIL schools $(n=35 \%)$. In addition, student teachers reported that mentor teachers at the teaching school provide good reasons for evaluating them in a particular way $(n=69 \%)$ as compared to WIL schools $(n=48 \%)$.

Another significant area of learning for student teachers is the mentor teachers' ability to connect student teachers' teaching to children's development. Here again, $62 \%$ of student teachers reported that the teaching school mentors were better able to do this, compared to $38 \%$ in WIL schools.

In Table 1 and Graph 1, a comparison between the frequency of responses of WIL schools vs. the teaching school is depicted. Table 1 presents all responses from not at all to very much and Graph 1 displays the quite a bit/quite a lot and very much responses only.

\section{THEMES DISTILLED FROM THE EXTANT RESEARCH ON THE TEACHING SCHOOL}

Three themes were distilled from the research on the teaching school, focusing specifically on how the teaching school operates as a space for student teachers to learn. 


\section{WIL $\mathrm{TS}$}
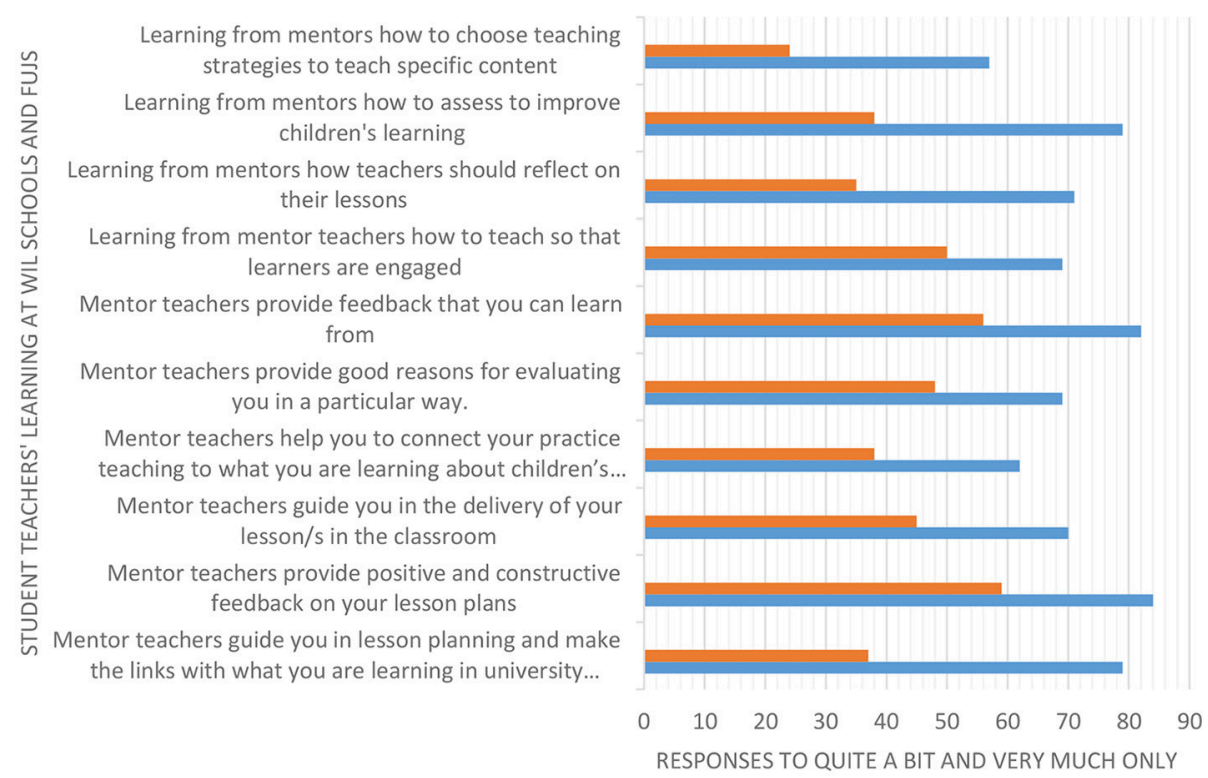

GRAPH 1 | Student teachers' reports of their mentoring experiences.

The first theme is that integrating a school into a teacher education program to connect the two worlds in which teacher education takes place is complicated. The second theme relates to the role of mentoring in the development of student teachers' professional practice knowledge. The third theme entails that it is possible to purposefully align key aspects of coursework learning and practice learning in schools in order to deepen student teacher learning.

\section{DISCUSSION}

Our research aimed at exploring what it takes to develop a "learningplace" conducive to student teachers' development of professional practice knowledge with specific reference to the role that mentoring plays. In this discussion, we combine the results from the two phases of the research.

\section{Integrating a School Into a Teacher Education Program}

A first finding, stemming from the analysis of the extant research on the teaching school is that integrating a school into a teacher education program to connect the two worlds in which teacher education takes place is complicated. As FeimanNemser and Buchman $(1985,63)$ say: It is indeed a "fallacious assumption that making connections between these two worlds is straightforward." This finding is important because it forms the backdrop to the mentoring practices in the school.

An assumption in setting up the teaching school was that the school would serve as a model environment for student teachers to learn the practice of teaching. However, this poses some difficult questions: who decides what a model school environment entails and what the criteria for a model environment are? And, should the emphasis be on preparing student teachers for schools that are or schools that should be? Here it is important to mention that the UJ teaching school is an everyday public school and the teachers in the school are employees of the local department of education and not the university. This means that they must implement the national curriculum and adhere to policies that govern public schools in South Africa. Even though there is memorandum of agreement between the university and the department of education, which allows for some leeway in organization and teaching in the school, the dual role of teachers in the school is challengingthey are often pulled in opposite directions to satisfy the needs of the university and their employer. A second challenge was with the appointment of teachers. Ideally, mentor teachers at the school should be expert teachers (Hattie, 2003) who could model exemplary practice and move into the mentorship role easily. However, as with other public schools, the usual processes and appointment criteria for public school teachers applied. This means that some teachers were appointed who struggle with the mentoring role. University-based teacher educators thus have to take up an additional role-mentoring the mentor teachers at the school.

Another challenge was with building a relationship of equivalence between the university and school. This is demanding and requires commitment from both parties to long-term dialogue to develop trust and respect.

The notion of a "neutral space" (Murray et al., 2014) or "third space" is a helpful heuristic to guide the development of a collaborative relationship between the teacher education institution and the school. Zeichner $(2010,92)$ says third space 
thinking promotes "the integration of what are often seen as competing discourses in new ways-an either/or perspective is transformed into a both/also point of view." The collective third space enables university-based teacher educators and mentor teachers to grapple jointly with the challenges of guiding and supporting student teacher learning. The aim of conversations within third space would be to arrive at a shared understanding of the vision for teacher education that should underpin both the coursework and the student teachers' learning at the school. The conversations would also aim at reconciling university expectations and school teachers' practices with a view to "generate both new understandings and enhanced practices" (Martin et al., 2011, 300). However, cultivating third space in partnerships is arduous. As Martin et al. (2011, 308) note, building joint practices in third space requires "embracing of complexity and uncertainty" and relinquishing of control or power. It would imply commitment from both the teacher education institution and the school to suspend assumptions about being right "and take the time to consider and explore the unfamiliar, question, and above all, listen to one another and possibly, silence the shrill critic within us all" (Kozleski, 2011, 257). This is easier said than done.

\section{Mentoring and the Development of Student Teachers' Professional Practice Knowledge}

An overarching finding is about the role of mentoring in the development of student teachers' professional practice knowledge. From an analysis of the published research on the teaching school, it is clear that teachers struggled to take up their mentoring roles successfully, despite development and support from the university. Not all teachers served as good role models for student teachers. Despite this, the teaching school mentors were still able to provide positive examples of good teaching and student teachers report that they benefited from observing the school teachers at work. When taken in conjunction with the 2018 questionnaire data, it appears as if many of the mentor teachers have grown in their roles as mentors over the last 7 years. Both the qualitative and quantitative data show that student teachers report learning a considerable amount from mentors in the teaching school. It becomes particularly evident when questionnaire responses about learning from mentors in the teaching school and WIL schools are compared-on all the items mentor teachers in the teaching school are rated more highly than those in WIL Schools.

Something that stood out in the qualitative data is that student teachers value the caring and support of their mentors. This is in line with literature. Hennissen et al. (2011) argue that emotional support and the experience of care are important to student teachers. In addition, students value task assistance. Similar to the study of Hennissen et al. (2011), student teachers in our study also identify support to help them hone their teaching skills (task assistance) as important. Also to them, a good mentor provides feedback and advice on lessons that they presented (Hobson, 2002). From the data, it is clear that student teachers judge mentoring experiences for their value for learning about the practicalities of teaching, in particular a clear sense of direction, advice and feedback (Cain, 2009). Another aspect they value is learning about classroom management, which in the conditions of South African schools, is pertinent-the classrooms in the majority of WIL schools are overcrowded, often catering for class sizes between 40 and 55 learners. Teaching and learning in such circumstances thus depend on an orderly classroom. In this respect student teachers are learning from good mentors how to teach in the schools that "are."

Missing from the data of student teachers' learning at WIL schools are the reasons behind mentor teachers' actions, or the "why" of practices. Providing hints, encouragement, and feedback are all examples of coaching as an element of traditional apprenticeship (Collins et al., 1991). However, if problems are simply pointed out to student teachers, without them fully understanding the contextual or contributing elements, they may be inclined to frame a response in a routinized manner (Loughran, 2002). Moreover, if student teachers are not challenged through critical questions, mentoring remains at the level of advisement, with student teachers' "knowing what" and "knowing how" improving, and their "knowing why" remaining under-developed.

It is particularly in this respect that the mentors in the teaching school distinguish themselves from those in the WIL schools. The teaching school mentors come closer to the idea of mentoring in the mode of a cognitive apprenticeship model. There are many references in the data to examples of mentoring practices that have the potential to foster "deeper insight into the cognitive aspects of teaching," (Meijer et al., 2002, 407). Such mentoring practices are valuable as they help student teachers to "recognize and challenge their assumptions, talk to their school experiences, consider alternatives, and contextualize theory within practice and practice within theory" (Segall, 2002 cited by Korthagen et al., 2006, 1036).

From the quantitative data it is clear that student teachers feel that they are learning more in the teaching school than in WIL schools. This is not surprising to us, because many of the WIL schools are considered to be low-functional ${ }^{6}$. Student teachers are thus clearly benefitting from their involvement at the teaching school where they experience a functional school with pockets of exemplary practice.

Here we single out the items from the questionnaire that we view as particularly important for developing professional practice knowledge.

Student teachers report learning more about the role of reflection in teaching at the teaching school (71\%) in comparison with WIL schools (35\%). This is probably due to the careful design of the student teachers' practicum at the teaching school and the explicit unpacking of what reflection involves with the mentor teachers.

A second aspect is that mentor teachers provide good reasons for evaluating student teachers in a particular way $(69 \%$ in the

\footnotetext{
${ }^{6} \mathrm{We}$ view a functional school as a well-run and well-managed school in which there is basic compliance in terms of teaching hours, curriculum coverage and good teaching practices. The school environment is clean and there is evidence of efforts to create an environment conducive for teaching and learning.
} 
teaching school as compared to $48 \%$ in WIL schools). This is most likely because student teachers, mentors and university teacher educators work with a commonly designed rubric, which places emphasis on the "why" during mentoring dialogues at the teaching school.

A third aspect is that the mentor teachers connect their teaching to children's development-here $62 \%$ of student teachers report that the teaching school mentors are doing this, compared to $38 \%$ in WIL schools. Though the responses in relation to the teaching school mentoring about this item is much more positive than the responses in relation to the WIL schools, we expected a more favorable outcome, seeing that child learning and development is the organizing principle of the program. In the existing teaching school research, learning about children and their development in the school is a prominent theme. Thusit seems as if the value of learning about child development that student teachers single out can be ascribed more to the structured course-work based observation tasks in the school than it can be to the mentoring.

Lastly, the data show that student teachers experience mentor teachers in the teaching school (79\%) linking their guidance of lesson planning to coursework in comparison to only some mentors (37\%) doing so in WIL schools.

\section{Alignment of Key Aspects of Coursework and Practice Learning}

A third overarching finding, evidenced by the findings from both phases of the data, is that it is possible to align key aspects of coursework learning and practice learning in a school as workplace learning site, and that student teachers view this as important for their learning. This is in line with numerous studies that point to the benefits of coordinating coursework and school experiences for student teacher learning (Strawhecker, 2005; Darling-Hammond, 2006; Moyer and Husman, 2006; Kansanen, 2014).

In the questionnaire and qualitative data student teachers point out the considerable congruence between their learning from coursework and their learning in the teaching school.

A strong theme in the extant research is that the courseworkbased observation tasks in the teaching school make the importance of child study "real" to student teachers. The twinning of the child study focus in the coursework with student teachers studying the same group of learners as they progress from Grade $\mathrm{R}$ to Grade 3 enabled the purposeful studying of children's development milestones in tandem with suitable pedagogies for teaching foundation phase learners.

\section{The Pattern Across the Two Phases of the Research}

Based on the pattern across the two phases of the research we claim that the teaching school plays a significant role as "learningplace" for developing student teachers' professional practice knowledge. There is considerable congruence between learning from coursework and learning in the teaching school. In addition, the mentoring in the teaching school shows evidence of laboratory practice work with elements of the model of cognitive apprenticeship. For the most part, the mentor teachers in the teaching school are, from the student teachers' perspective, executing their mentoring role competently. Thus, purposive mentoring is indeed influential for fostering the development of student teachers' professional practice knowledge. However, we argue that mentoring as such is not sufficient for developing student teachers' professional practice knowledge and for bridging the perceived theory-practice schism. We contend that a program design that incorporates the school (as learning site) as a central component of the curriculum is crucial. Also, student teacher observations at the school need to be directed, with particular emphasis on foregrounding core aspects from coursework and the expectation that student teachers will explicitly link their observations to coursework. In this process, it is also possible to highlight discrepancies between the coursework and experiences at the school, which could become powerful "generative themes" (Shor, 1992) to explore during coursework.

Furthermore, our research shows that a teacher educationfocused partnership with a school allows for intentional development of student teachers' professional practice knowledge in ways that would be difficult to achieve without a close collaboration. Darling-Hammond et al. (2017) note that in virtually all of the countries with high-performing school systems, school-university partnerships are developed or strengthened to provide practical experiences for pre-service teachers for connecting theory and practice.

The primary school teacher education program reported on in this paper is undoubtedly working, albeit on a small scale as our student numbers are limited. In South Africa, there is a dire need for well-educated foundation phase teachers (Green et al., 2014) and we were left pondering how we could broaden access to this program.

\section{Going Forward}

The solution that we shall be pursuing regarding how to broaden access to the program is to offer the university coursework program online in partnership with selected schools who offer full-time school placement to student teachers-the schools will provide the practice learning setting. In order to qualify as a partner, schools would need to meet specific criteria of functionality in order for them to operate in a similar fashion to the current university teaching school. The school teachers will also serve as mentors for student teachers. This model is advantageous for extending the teacher education model but it also means that the university will invest in development of the school in a reciprocally beneficial manner.

We are aware that this will be a challenging endeavor. Even though we can claim with some confidence that the teacher education model developed at the UJ Soweto Campus is successful, our experience of the past few years with the teaching school has taught us the complicated nature of a true partnership. In order to establish a partnership that will enable the type of teacher education that we espouse, it would be crucial for the university teacher educators to have clarity on the following questions prior to exploring these also with prospective partner schools. What type of 
teacher does the program wish to deliver? What is the core unifying idea that underlies the program design? These are program identity questions. Currently we claim (with some conviction) that the program is practice-based and inquiryoriented and consequently that student teachers acquire a strong professional practice knowledge base in the program and the inclination and skills to be inquiry-oriented teachers. Does this purported identity permeate the program design and how the program will be presented online? What does this mean for the mentoring of school-based student teachers in terms of the expectation of the mentor teachers at the partnership schools? What does this mean for the mentoring development program that will be presented to the mentor teachers? How will the development program reflect the identity of the teacher education program?

Once in conversation with prospective schools it is also crucial to arrive to a shared understanding of the type of partnership that is envisaged as well as what the respective roles of the stakeholders would entail. This conversation will have to be ongoing once the partnership has been established. Continuous collaboration, coordination and communication (Jones et al., 2016) would be crucial to ensure that the university-based teacher educators and school-based mentor teachers work as a team toward the common goal of good teacher education. This model also implies a new role for teacher educators. University-based teacher educators, offering the program, may have to shift into another role-and become mentors for the school-based mentor teachers-in the process modeling what mentoring entails to mentor teachers while remaining sensitive to developing a partnership of equals.

\section{CONCLUSION}

In this paper we explored our research into what it takes to develop a "learningplace" conducive to developing student

\section{REFERENCES}

Barrow, R. (1990). Teacher education: theory and practice. $\mathrm{Br}$. J. Educ. Stud. 38, 308-318. doi: 10.1080/00071005.1990.99 73859

Cain, T. (2009). Mentoring trainee teachers: how can mentors use research? Ment. Tutor. 17, 53-66. doi: 10.1080/13611260802233498

Cheng, M. M. H., Tang, S. Y. F., and Cheng, A. Y. N. (2012). Practicalising theoretical knowledge in student teachers' professional learning in initial teacher education. Teach. Teach. Educ. 28, 781-790. doi: 10.1016/j.tate.2012.02.008

Childs, A., Edwards, A., and McNicholl, J. (2014). "Developing a multi-layered system of distributed expertise: what does cultural historical theory bring to understandings of workplace learning in school-university partnerships?," in Workplace Learning in Teacher Education, eds O. McNamara, J. Murray, and M. Jones (Dordrecht: Springer), 29-45.

Clarke, A., Triggs, V., and Nielsen, W. (2014). Cooperating teacher participation in teacher education: a review of the literature. Rev. Educ. Res. 84, 163-202. doi: 10.3102/0034654313499618

Collins, A., Brown, J. S., and Holum, A. (1991). Cognitive apprenticeship: making thinking visible. Am. Educ. 15, 6-11.

Conway, P. F., Murphy, R., and Rutherford, V. (2014). "Learningplace' practices and pre-service teacher education in Ireland: knowledge generation, teachers' professional practice knowledge and the role that mentoring plays in this regard. We conclude that a teaching school, if integrated into the program design and delivery, provides a rich practice learning site for student teachers. In addition, mentoring in cognitive apprenticeship mode could indeed be a powerful contributor to student teachers' professional development. However, the overall programme design is decisive. We argue that the preparation of teachers with strong professional practice knowledge requires attention to four interrelated aspects of program design, namely organizational structures, curriculum, teacher education pedagogy (McDonald et al., 2014), and program identity. Four aspects need to be addressed in an integrated manner: "why" (the program identity), "where" (the teacher education sites), "what" (the curriculum), and "how" (the teacher education pedagogy). We are also of the view that addressing these aspects in an integrated manner would be difficult without working closely with one or more partnership schools.

\section{ETHICS STATEMENT}

This study was carried out in accordance with the guidelines as set out by the University of Johannesburg, Faculty of Education Ethics committee and the guidelines of the Funda UJabule committee (governing body) overseeing research in the teaching school. All participants gave written informed consent in accordance with the Declaration of Helsinki.

\section{AUTHOR CONTRIBUTIONS}

All authors listed have made a substantial, direct and intellectual contribution to the work, and approved it for publication. partnerships and pedagogy," in Workplace Learning in Teacher Education, eds O. McNamara, J. Murray, and M. Jones (Dordrecht: Springer), 221-241.

Darling-Hammond, L. (2000). How teacher education matters. J. Teach. Educ. 51, 166-173. doi: $10.1177 / 0022487100051003002$

Darling-Hammond, L. (2006). Constructing 21st-century teacher education. J. Teach. Educ. 57, 300-314. doi: 10.1177/0022487105285962

Darling-Hammond, L., and Baratz-Snowden, J. (2005). A Good Teacher in Every Classroom: Preparing the Highly Qualified Teachers Our Children Deserve. San Francisco, CA: John Wiley and Sons.

Darling-Hammond, L., Burns, D., Campbell, C., Goodwin, A. L., Hammerness, K., Low, E., et al. (2017). Empowered Educators: How High-Performing Systems Shape Teaching Quality Around the World. Kindle Edition (San Francisco, CA: Wiley).

Darling-Hammond, L., Hammerness, K., Grossman, P., Rust, F., and Shulman, L. (2005). "The design of teacher education programs," in Preparing Teachers for a Changing World: What Teachers Should Learn and be Able to do, eds L. DarlingHammond and J. Bransford (San Francisco, CA: Jossey-Bass), 390-441.

Day, C. (1998). Re-thinking school-university partnerships: A Swedish case study. Teach. Teach. Edu. 14, 807-819.

Department of Basic Education and Department of Higher Education and Training (DBE and DHET) (2011). Integrated Strategic Planning Framework for Teacher Education and Development in South Africa. Pretoria: Government Printer. 
Department of Higher Education and Training. (2015). Revised Policy on the Minimum Requirements for Teacher Education Qualifications. National Qualifications Framework Act 67 (2008). Government Gazette, Vol. 38487 No. 596. Pretoria: Government Printer.

Dewey, J. (1904). "The relation of theory to practice in education," in The Third Yearbook of the National Society for the Scientific Study of Education: Part I: The Relation of Theory to Practice in the Education of Teachers (Chicago, IL: University of Chicago Press), 9-30.

Dewey, J. (1933). How We Think: A Restatement of the Relation of Reflective Thinking to the Educative Process. Boston, MA: Heath.

Education Labour Relations Council (2009). Resource Document. Teacher Development Summit, 29th June-2nd July.

Eisner, E. W. (2002). From episteme to phronesis to artistry in the study and improvement of teaching. Teach. Teach. Educ. 18, 375-385. doi: 10.1016/S0742-051X(02)00004-5

Fairbanks, C. M., Freedman, D., and Kahn, C. (2000). The role of effective mentors in learning to teach. J. Teach. Edu. 51, 102. doi: 10.1177/002248710005100204

Feiman-Nemser, S. (2001). From preparation to practice. Designing a continuum to strengthen and sustain teaching. Teach. Coll. Rec. 103, 1013-1055. doi: 10.1111/0161-4681.00141

Feiman-Nemser, S. (2008). “Teacher learning: how do teachers learn to teach?”, in Handbook of Research on Teacher Education: Enduring Questions in Changing Contexts, eds M. Cochran-Smith, S. Feiman-Nemser, D. J. McIntyre and K. Demers (New York, NY: Routledge), 697-705.

Feiman-Nemser, S., and Buchman, M. (1985). Pitfalls of experience in teacher preparation. Teach. Coll. Rec. 87, 53-65.

Flores, M. A. (2016). "Teacher education curriculum," in International Handbook of Teacher Education, eds J. Loughran and M. L. Hamilton (Singapore: Springer), $187-230$.

Gaventa, J. (2007). "Levels, spaces and forms of power: analysing opportunities for change," in Power in World Politics, eds F. Berenskoetter and M. J. Williams (New York, NY: Routledge), 204-223.

Gravett, S. (2012). Crossing the "theory-practice divide": learning to be (come) a teacher. South Afr. J. Childh. Educ. 2:14.

Gravett, S., and Jiyane, L. (in press). The practice learning experiences of student teachers at a rural campus of a South African University. South Afr. J. Childh. Educ.

Gravett, S., Petersen, N., and Petker, G. (2014). Integrating foundation phase teacher education with a 'teaching school' at the University of Johannesburg. Educ. Change 18, 107-119. doi: 10.1080/16823206.2013.877357

Gravett, S., and Ramsaroop, S. (2017). Teaching schools as teacher education laboratories. South Afr. J. Childh. Educ. 7:8.

Green, W., Adendorff, M., and Mathebula, B. (2014). 'Minding the gap?' A national foundation phase teacher supply and demand analysis: 2012-2020. South Afr. J. Childh. Educ. 4, 2-23. doi: 10.4102/sajce.v4i3.222

Hattie, J. (2003). "Teachers make a difference: what is the research evidence?", in Paper Presented at the Australian Council for Educational Research Annual Conference: Building Teacher Quality (Melbourne, VIC). Available online at: http://www.educationalleaders.govt.nz/

Henning, E., Van Rensburg, W. A., and Smit, B. (2004). Finding Your Way in Qualitative Research. Pretoria:Van Schaik.

Hennissen, P., Crasborn, F., Brouwer, N., Korthagen, F., and Bergen, T. (2011). Clarifying pre-service teacher perceptions of mentor teachers' developing use of mentoring skills. Teach. Teach. Educ. 27, 1049-1058. doi: 10.1016/j.tate.2011.03.009

Hobson, A. J. (2002). Student teachers' perceptions of school-based mentoring in initial teacher training (ITT). Ment. Tutor. 10, 5-20. doi: $10.1080 / 13611260220133117$

Horn, I. L., and Campbell, S. (2015). Developing pedagogical judgment in novice teachers: mediated field experience as a pedagogy for teacher education, Pedagogies. Int. J. 10, 149-176. doi: 10.1080/1554480X.2015.1021350

Intrator, S., and Kunzman, R. (2009). Grounded: practicing what we preach. J. Teach. Educ. 60, 512-519. doi: 10.1177/0022487109348598

Jones, M., Hobbs, L., Kenny, J., Campbell, C., Chittleborough, G., Gilbert, A., et al. (2016): Successful university-school partnerships: an interpretive framework to inform partnership practice. Teach. Teach. Educ. 60, 108-120. doi: $10.1016 /$ j.tate.2016.08.006
Kansanen, P. (2014). "Teaching as a master's level profession in Finland: theoretical reflections and practical solutions," in Workplace Learning in Teacher Education. International Practice and Policy, eds O. Namara, J. Murray and M. Jones (London: Springer), 279-292.

Kessels, J., and Korthagen, F. A. J. (2001). "The relation between theory and practice: back to the classics," in Linking Practice and Theory. The Pedagogy of Realistic Teacher Education, ed F. A. J. Korthagen (Mahwah, NJ: Taylor and Francis), 20-31.

Korthagen, F. A. (2010). Situated learning theory and the pedagogy of teacher education: towards an integrative view of teacher behavior and teacher learning. Teach. Teach. Educ. 26, 98-106. doi: 10.1016/j.tate.2009.05.001

Korthagen, F. A. (2016). "Pedagogy of teacher education," in International Handbook of Teacher Education, eds J. Loughran and M. L. Hamilton (Singapore: Springer), 311-346.

Korthagen, F. A. J., Loughran, J., and Russell, T. (2006). Developing fundamental principles for teacher education programs and practices. Teach. Teach. Educ. 22, 1020-1041. doi: 10.1016/j.tate.2006.04.022

Kosnik, C., and Beck, C. (2009). Priorities in teacher education. The 7 key elements of pre-service preparation. New York, NY: Routledge.

Kozleski, E. (2011). Dialectical practices in education: creating third space in the education of teachers. Teach. Educ. Special Educ. 34, 250-259. doi: $10.1177 / 0888406411410077$

Krull, E. (2005). Mentoring as a means for supporting student and beginning teachers' practice-based learning. TRAMES J. Hum. Soc. Sci. 9, 143-158.

Loughran, J. J. (2002). Effective reflection practice: in search of meaning in learning about teaching. J. Teach. Educ. 53, 33-43. doi: 10.1177/00224871020530 01004

Loughran, J. J., and Hamilton, M. L. (2016). "Developing an understanding of teacher education" in The International Handbook of Teacher Education, eds J. Loughran and M. L. Hamilton (Singapore: Springer), 3-22.

Loukomies, A., Petersen, N., and Lavonen, J. (2018). A Finnish model of teacher education informs a South African one: a teaching school as a pedagogical laboratory. South Afr. J. Childh. Educ. 8:593. doi: 10.4102/sajce.v8i1.593

Martin, S. D., Snow, J. L., and Franklin Torrez, C. A. (2011). Navigating the terrain of third space: tensions with/in relationships in school-university partnerships. J. Teach. Educ. 62, 299-311. doi: 10.1177/0022487110396096

Mattsson, M., Eilertsen, T. V., and Rorrison, D. (2012). A Practicum Turn in Teacher Education, Vol. 6. Dordrecht: Springer Science and Business Media.

McDonald, M., Kazemi, E., Kelley-Petersen, M., Mikolasy, K., Thompson, J., Valencia, S. W. et al. (2014). Practice makes practice: Learning to teach in teacher education. Peabody J. Teach. Edu. 89, 500-515. doi: 10.1080/0161956X.2014.938997

McIntyre, D. (1995). Initial teacher education as practical theorising: a response to Paul Hirst. Br. J. Educ. Stud. 43, 365-383. doi: 10.1080/00071005.1995.99 74045

McNamara, O., Jones, M., and Murray, J. (2014). "Framing workplace learning," in Workplace Learning in Teacher Education. International Practice and Policy, eds O. McNamara, O. Murray and M. Jones (London: Springer), $1-28$.

Meijer, P. C., Zanting, A., and Verloop, N. (2002). How can student teachers elicit experienced teachers' practical knowledge? Tools, suggestions, and significance. J. Teach. Educ. 53, 406-419. doi: 10.1177/002248702237395

Merriam, S. B. (1998). Qualitative Research and Case Study Applications in Education. San Francisco, CA: Josey-Bass.

Moyer, P. S., and Husman, J. (2006). Integrating coursework and field placements: the impact on preservice elementary mathematics teachers' connections to teaching. Teach. Educ. Q. 33, 37-56. Available online at: https://www.jstor.org/ stable/23478733

Murray, J., McNamara, O., and Jones, M. (2014). "Improving workplace learning in teacher education," in Workplace Learning in Teacher Education, eds O. McNamara, J. Murray, and M. Jones (Dordrecht: Springer), 293-315.

Mutemeri, J., and Chetty, R. (2011). An examination of universityschool partnerships in South Africa. South Afr. J. Educ. 31, 505-517. doi: $10.15700 /$ saje.v31n4a325

Odendaal, R. (2015). What is the Potential Role of Case-Based Teaching to Enhance Student Teachers' Development as Prospective Teachers? Master's Dissertation, Faculty of Education, University of Johannesburg. 
Orland-Barak, L. (2017). "Learning teacher agency in teacher education," in The SAGE Handbook of Research on Teacher Education, eds D. J. Clandinin and J. Husu (London, UK: SAGE Publications. Kindle Edition), 247-252.

Ramsaroop, S., and Gravett, S. (2017). The potential of teaching schools in enabling student teacher learning for the teaching profession. J. Curr. Stud. 49, 848-865. doi: $10.1080 / 00220272.2017 .1325516$

Robinson, M. (2015). Teaching and Learning Together: The Establishment of Professional Practice Schools in South Africa. A Research Report for the Department of Higher Education and Training. Stellenbosch University and the Cape Peninsula University of Technology, South Africa.

Segall, A. (2002). Disturbing Practice: Reading Teacher Education as Text. New York, NY: Peter Lang.

Shor, I. (1992). Empowering Education. Critical Teaching for Social Change. Chicago, IL: The University of Chicago Press.

Smagorinsky, P., Cook, L. S., and Johnson, T. S. (2003). The twisting path of concept development in learning to teach. Teach. Coll. Rec. 105, 1399-1436. doi: 10.1111/1467-9620.00296

Smith, K., and Ulvik, M. (2014). "Learning to teach in Norway: a shared responsibility" in Workplace Learning in Teacher Education. International Practice and Policy, eds O. McNamara, J. Murray and M. Jones (London: Springer), 261-277.

Stanulis, R. N., and Russell, D. (2000). "Jumping in": trust and communication in mentoring student teachers. Teach. Teach. Educ. 16, 65-80. doi: 10.1016/S0742-051X(99)00041-4

Strawhecker, J. (2005). Preparing elementary teachers to teach mathematics: how field experiences impact pedagogical content knowledge. IUMPST J. 4, 1-12. Available online at: http://www.k-12prep.math.ttu.edu/journal/about. shtml
Ulvik, M., and Smith, K. (2011). What characterises a good practicum in teacher education? Educ. Inquiry 2, 517-536. doi: 10.3402/edui.v2i3.21997

White, S., and Forgasz, R. (2016). "The practicum: the place of experience?" in International Handbook of Teacher Education, eds J. Loughran and M. L. Hamilton (Singapore: Springer), 231-266.

Zeichner, K. (2010). Rethinking the connections between campus courses and field experiences in college-and university-based teacher education. J. Teach. Educ. 61, 89-99. doi: 10.1177/00224871093 47671

Zeichner, K., and Bier, M. (2015). "Opportunities and pitfalls in the turn toward clinical experience in U.S. teacher education," in Rethinking Field Experiences in Preservice Teacher Rethinking Field Experiences in Preservice Teacher Preparation: Meeting New Challenges for Accountability Preparation: Meeting New Challenges for Accountability, ed E. R. Hollins (New York, NY: Routledge), $20-46$.

Conflict of Interest Statement: The authors declare that the research was conducted in the absence of any commercial or financial relationships that could be construed as a potential conflict of interest.

Copyright $\odot 2019$ Gravett, Petersen and Ramsaroop. This is an open-access article distributed under the terms of the Creative Commons Attribution License (CC BY). The use, distribution or reproduction in other forums is permitted, provided the original author(s) and the copyright owner(s) are credited and that the original publication in this journal is cited, in accordance with accepted academic practice. No use, distribution or reproduction is permitted which does not comply with these terms. 